\title{
The Scottish coalition
}

\section{agreement}

\author{
by Philip Goldenberg
}

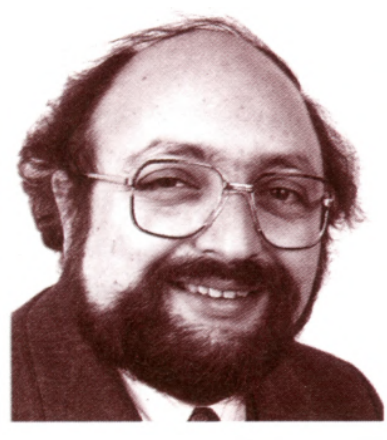

Philip Goldenbery

The first Scottish parliamentary elections in May this year were followed by a landmark coalition agreement between the Scottish Labour Party and the Scottish Liberal Democrats. Philip Goldenberg was involved in the drafting of wording on which Part III of the agreement was based and here analyses the significance of the Partnership Executive.

$\mathrm{I}$ the words of Disraeli's well-known aphorism, 'England does not like coalitions'. Scotland would appear to be different! Opinion poll evidence suggests that the formation of the 'Partnership Executive' following the first Scottish parliamentary elections last May has been welcomed - at least so far - as a constructive attempt to work across party boundaries.

At the time of such formation, journalistic commentary focused almost exclusively (and not unreasonably) on the policy content of the agreement between the Scottish Labour Party and the Scottish Liberal Democrats, with particular reference to the issue of tuition fees. This latter, to which reference is made below, was dealt with by establishing an independent Committee of Inquiry with both political parties free to submit evidence independently.

What escaped journalistic attention was Part III of the agreement, which is reproduced in the text-box accompanying this article. This contained the structural provisions of the agreement and constitutes the only recent UK example of a formal arrangement for a full-blown coalition. The purpose of this article is to analyse it.

\section{FORMS OF POLITICAL CO-OPERATION}

First some background. There is a kaleidoscopic variety of ways in which political parties can co-operate together in sustaining an administration - the background circumstances and the parliamentary arithmetic being obviously important factors on each occasion.

For example, in March 1974 the then Liberal Party declined an offer from Ted Heath to join a Conservative-led coalition government, principally for three reasons:

(a) it would not have had a Parliamentary majority;

(b) the Conservative Party indicated that it was not prepared to make any significant policy changes, so that effectively the Liberal Party would have joined a Conservative
Government and been in what one might term the 'reverse harlot position', with total (collective) responsibility and no power; and

(c) while it might have been unclear who had won the February 1974 General Election, it was abundantly clear that the Conservative Party, having called that election while in possession of an overall majority, had lost it.

In 1977, the then Labour Government, having lost its (previously very narrow) overall majority, invited the then Liberal Party to enter into a parliamentary arrangement to support the government from the opposition benches in return for rights of consultation. One key objective of the Liberal Party - to obtain proportional representation for the forthcoming first elections to the European Parliament - failed because of inadequate support from Labour back-benchers; this demonstrated the need for any co-operation arrangement to have the support of both parliamentary parties, and not merely of the government as such.

Twenty years later, the Blair Government, although elected on a landslide majority, wished to bring the Liberal Democrats into a co-operative arrangement in relation to the programme of constitutional reform which they had jointly agreed in what became known as the Cook-Maclennan Agreement. Learning from experience, the Liberal Democrats had decided in advance that they would not be prepared to accept a Heath-type offer of minority participation in a Labour Government; had the parliamentary arithmetic been different, they might well have considered participation in a coalition government (this distinction is not merely semantic, and is discussed below). Instead, they suggested a Joint Cabinet Committee which would enable them to co-operate in a defined area of policy while retaining their independence on other topics. Nor, incidentally, was this device without precedent. For example:

(a) in 1905, members of the outgoing Conservative Government remained on the Committee for Imperial Defence; and 
(b) as recently as the late 1940s (and no doubt influenced by the National Government which had conducted the Second World War), the Attlee Government invited senior Conservatives to serve on a Joint Cabinet Committee on Defence.

\section{SCOTLAND 1999}

The first Scottish parliamentary elections in modern times produced a parliamentary situation of no overall majority. On the arithmetic, and also in terms of political compatibility (not least against the background not only of Westminster cooperation between New Labour and the Liberal Democrats but also of the Scottish Constitutional Convention, which was the Scottish Parliament's midwife), a coalition between the Scottish
Labour Party and the Scottish Liberal Democrats made natural sense if it could be achieved.

Thus was born the Scottish Partnership Executive. Perhaps to the surprise of the Scottish Labour Party, the Scottish Liberal Democrats required, as a price for their support, not only a full and lengthy agreement on policy, but also a genuine coalition structure. The latter was achieved by Part III of the Scottish Coalition Agreement (set out in the accompanying text-box).

The Partnership Agreement adopts, and spells out at length, the doctrine of collective responsibility. However, in the nature of a coalition government, this is extended to reflect the fact that there will be mechanisms for resolving disputes. The normal such mechanism is a Coalition Committee which has equal representation from each of the coalition partners (regardless of

\title{
THE SCOTTISH COALITION AGREEMENT
}

\author{
(extract)
}

\section{Part III: Working Together}

\section{Introduction}

To work effectively and deliver their programme the partners will need goodwill, mutual trust and agreed procedures which foster collective decision-making and responsibility while respecting each party's identity.

We are agreed that close consultation between the First Minister and the Deputy First Minister will be the foundation of the Partnership's success. Consultation needs to cover all aspects of the conduct of the Executive's business, including the allocation of responsibilities, the Executive's policy and legislative programme, the conduct of its business and the resolution of disputes.

\section{Collective responsibility}

Collective responsibility is accepted by the partners to mean that:

(a) all the business of the Executive, including decisions, announcements, expenditure plans, proposed legislation and appointments, engages the collective responsibility of the Executive as a whole and must be handled with an appropriate degree of consultation and discussion so as to ensure the support of all Ministers;

(b) Ministers have the opportunity to express their views frankly as decisions are reached;

(c) opinions expressed and advice offered within the Executive remain private;

(d) decisions of the Executive are binding on and supported by all Ministers; and

(e) mechanisms for sharing information and resolving disputes are followed.

To achieve this the Executive will agree and publish formal documents setting out the principles of collective decision- making and the procedures to be followed to promote the good conduct of business.

\section{Portfolios}

The allocation of portfolios between the partners will be agreed by the leaders of the partnership parties. Ministerial appointments will be made by the First Minister, following consultation with the Deputy First Minister.

\section{The role of the Deputy First Minister}

The parties agree that, subject to the approval of the Parliament, the Leader of the Scottish Liberal Democrats should be nominated to hold the office of Deputy First Minister in the Partnership Executive.

It is essential that the Deputy First Minister is kept fully informed across the range of Executive business so that he can engage in any issue where he considers that appropriate. The procedures to be established for handling business within the Executive will require officials to copy all relevant material to the offices of the leaders of both parties in the Executive. The Deputy First Minister will have appropriate official, political and specialist support to enable him to discharge his role effectively.

\section{The parties' support for the Executive in Parliament}

The two parliamentary parties will operate in support of the Partnership Executive but each will make its own business management arrangements, including measures to ensure effective Party support for the Executive.

\section{Duration and ratification of this agreement}

The partners' objective is that this agreement will cover the four years of the first Scottish Parliament and to achieve this they will make every effort to resolve any disagreements which may arise and threaten its continued operation. 
their respective numerical parliamentary strengths), and indeed may include non-parliamentarians such as senior party officers. This is not a specific provision of the Scottish Agreement, but nor is it ruled out; there is merely a bland statement that the partners will 'make every effort to resolve any disagreements which may arise' and threaten continuing co-operation.

An interesting application of this will be what happens following the report of the Independent Committee of Inquiry on tuition fees. The policy section of the Coalition Agreement provides that there will be a collective discussion of the Partnership Executive's response to the Committee Inquiry, but that its Liberal Democrat members are not bound in advance. Logically, this must also be true of its Labour members! The realistic options in the event of disagreement are presumably the break-up of the Partnership Executive or an abandonment of collective responsibility on this one issue.

\section{DEPUTY FIRST MINISTER}

The key to the functioning of the Partnership Executive is the role of the Deputy First Minister. The agreement states that 'close consultation' between the First Minister and the Deputy First Minister will be 'the foundation of the Partnership's success', and goes on to provide that consultation needs to cover all aspects of the conduct of the Executive's business, including the allocation of responsibilities, the Executive's policy and legislative programme, the conduct of its business and the resolution of disputes. Specifically, it is agreed that the allocation of portfolios is a matter for agreement between them, and that ministerial appointments, while made by the First Minister, will be the subject of consultation with the Deputy First Minister

As an exemplar of this, the Deputy First Minister has full access to all the First Minister's papers. He is to be kept 'fully informed' across the range of Executive business, so that he can engage in any issue he considers appropriate. Indeed, it is specifically provided that he will have his own office and staff (in the language of the Agreement, 'appropriate official, political and specialist support to enable him to discharge his role effectively').

This demonstrates that participation by the Liberal Democrats as minority partners in the Executive is no mere bolt-on, as was offered by Ted Heath in 1974 (but rejected), and rejected again by the Liberal Democrats in their pre-1997 General Election contingency planning for a 'hung Parliament'. Emphatically, the Partnership Executive is not a Scottish Labour Government pursuing a Labour agenda but with Liberal Democrat participation; it is a genuine coalition government in terms of both policy and operation.

\section{PARLIAMENTARY MANAGEMENT}

Learning from their 1977/8 experience under the Lib-Lab Pact, the Liberal Democrats insisted that both political parties would be whipped in support of the Partnership Executive, although each would make its own business management arrangements, the latter to include measures to ensure 'effective Party support' for the Executive. Presumably the last point is a message directed to Old Labour elements in the Scottish Labour Party and to any Liberal Democrats who might be less than enthusiastic about co-operation with the Labour Party.

Significantly, one of the four ministerial posts (two in the Executive, two outside) which the Liberal Democrats took was that of Deputy Business Manager, thereby reinforcing both their influence on the Executive's business programme and their shared responsibility for its management.

\section{CONCLUSION}

In a very British way, the UK, as a result of the programme of constitutional reform agreed between the Labour Government and the Liberal Democrats, is moving sideways towards a written constitution. Devolution to Scotland and Wales; the reform (however half-hearted) of the House of Lords; the establishment of a mayor and strategic authority for London; the creation of regional development authorities which will surely over a period, albeit perhaps not all at once, be given democratic legitimisation by an electoral process; the extension and increasing use of judicial review; whatever emerges in institutional terms from the Northern Ireland peace process; the accession of the UK to the European Convention on Human Rights; and an (however inadequate and watered-down) Freedom of Information Act - the combined effect is a fundamental reshaping of British institutions, with a plethora of legal consequences. No longer will it be possible to say, as Jim Callaghan is reputed to have observed, that 'The British constitution is what happens'. Instead, there is a gradual infusion of the rule of law into areas previously governed by illdefined usage and convention.

Nor is it sensible to imagine that the process is concluded. The 'West Lothian Question' (the concomitant inability of English MPs to vote on devolved Scottish and Welsh (and eventually Northern Irish) matters, while MPs from these areas can vote on English matters) remains unresolved, and will only be answered by the adoption of a proper federal structure. This in turn will fit well with the future development of the European Union into an Europe de Régions rather than one composed of nation states.

In addition, with proportional representation in place for all non-Westminster elections in Northern Ireland, for the new authoritics in Scotland, Wales and London, for European parliamentary elections, and likely to be adopted for Scottish local elections and perhaps also for local elections in England and Wales, its tide, already lapping around the ramparts of Westminster, will surely eventually break through there too. This will inevitably mean that, whatever Disraeli may have thought, coalition government at Westminster may become the norm rather than the exception; and Scotland will have provided the test-bed. (e)

\section{Philip Goldenberg MA (Oxon) FRSA FSALS}

\section{Partner in City Solicitors SJ Berwin \& Co, specialising in company law.}

As a Liberal Democrat Philip Goldenberg was involved, in the run-up to the 1997 General Election, in that party's contingency planning for co-operation with the Labour Party on a spectrum from a full-blown coalition to the Joint Cabinet Committee, which he conceived and which subsequently became a reality. The wording of Part III of the Scottish Coalition Agreement was based on his original contingency drafting for Westminster. 